\section{Flowering Responses of Easter Cactus Clones at Optimal and Supraoptimal Temperatures}

\author{
Thomas H. Boyle \\ Department of Plant and Soil Sciences, French Hall, University of \\ Massachusetts, Amherst, MA 01003
}

Additional index words. ornamental plant, Rhipsalidopsis gaertneri, Rhipsalidopsis $\times$ graeseri, Rhipsalidopsis rosea

\begin{abstract}
The effects of temperature and clonal genotype on flowering of Easter cactus (Rhipsalidopsis Britton \& Rose) were investigated in two experiments. Plants of 'Crimson Giant', 'Evita', 'Purple Pride', and 'Red Pride' were exposed to 6 weeks of either 10C or 18C night temperature (NT) under 9- to 9.5-hour natural daylengths (ND), and afterwards were forced at 18C NT and long days (LD). All clones produced fewer flowers when exposed to $18 \mathrm{C}$ and $\mathrm{ND}$ as compared with $10 \mathrm{C}$ and $\mathrm{ND}$; however, the clones varied significantly in their flowering responses. Relative to $10 \mathrm{C}$ NT and ND, exposure to 18C NT and ND resulted in an $84 \%$ to $95 \%$ decrease in the number of flower buds for 'Evita', 'Purple Pride', and 'Red Pride', but only a 50\% decrease in the number of flower buds for 'Crimson Giant'. In another experiment, 23 clones were exposed to 18C NT and 8-hour short days for 6 weeks, then forced at $18 C$ NT and LD. The clones exhibited differences in percentage of plants flowering, days to flowering, percentage of apical phylloclades flowering, and number of flower buds. 'Crimson Giant' outperformed all other clones. Further breeding and selection may yield genotypes that flower more prolifically at $\mathbf{1 8 C}$ minimum than current cultivars.
\end{abstract}

Easter cactus is a prominent flowering potted plant in northern Europe, but is a relatively new crop in North America (Boyle, 1991a; Nell, 1988). Plants cultivated as Easter cactus are clonally propagated selections of Rhipsalidopsis gaertneri (Regel) Moran, $R$. rosea (Lagerheim) Britton \& Rose, and their interspecific hybrids $[R$. × graeseri (Werdermann) Moran] (Barthlott, 1979; Liberty Hyde Bailey Hortorium, 1976).

Flowering in Easter cactus is controlled by temperature and photoperiod (Boyle, 1990, 1991b; Boyle et al., 1988; Peters and Rünger, 1971; Rünger, 1960). The optimum temperature for flower initiation is $\approx 10 \mathrm{C}$ (Peters and Rünger, 1971; Rünger, 1960). Easter cactus exhibits considerable clonal variation in the optimal duration at $10 \mathrm{C}$ for prolific flowering: $R$. gaertneri 'Crimson Giant' requires 6 to 8 weeks (Boyle, 1991b), $R . \times$ graeseri requires 10 weeks (Rünger, 1960), and $R$. rosea requires 12 to 16 weeks (Boyle, 1990). Flowering is inhibited at temperatures $>15 \mathrm{C}$ (Boyle, 1990, 1991b; Peters and Rünger, 1971; Rünger, 1960), but the degree of inhibition varies among

Received for publication 8 Sept. 1994. Accepted for publication 20 Jan. 1995. Publication no. 3147 of the Massachusetts Agricultural Experiment Station. I thank H. de Vries of J. de Vries Potplantencultures bv, Aalsmeer, The Netherlands, for donating cuttings and for providing partial funding for this study. The cost of publishing this paper was defrayed in part by the payment of page charges. Under postal regulations, this paper therefore must be hereby marked advertisement solely to indicate this fact. clones. At $18 \mathrm{C}$ minimum, flowering is only partially inhibited in $R$. gaertneri 'Crimson Giant' (Boyle, 1991b; Boyle et al., 1988) but is almost completely inhibited in $R$. rosea (Boyle, 1990). The flowering responses of $R$. $\times$ graeseri at $18 \mathrm{C}$ minimum have not been reported, but flower initiation is suppressed completely or partially at 20C (Rünger, 1960). At $10 \mathrm{C}, R$. gaertneri will initiate flowers under photoperiods ranging from $10 \mathrm{~h}$ to continuous irradiation (Peters and Rünger, 1971). At 18C, R. gaertneri responds as a short-longday plant (SLDP) for flowering (Boyle et al., 1988); the critical daylength for the short-day (SD) phase is between 11 and $12 \mathrm{~h}$ (Boyle, 1991b), whereas the critical daylength for the long-day (LD) phase is $\approx 12 \mathrm{~h}$ (Boyle et al., 1988).

Currently, Easter cactus is marketed from February to May (Nell, 1988), but extending the marketing period to other times of the year would be desirable. For example, red-flowered cultivars would be useful if they could be scheduled as a Christmas crop. In many regions of North America, however, it may be difficult to produce Easter cactus for Christmas due to the inability to maintain greenhouses at $10 \mathrm{C}$ for flower initiation. This statement is based on the following assumptions: 1) budded plants would be marketed in early December; and 2) plants would require 6 weeks at $10 \mathrm{C}$ followed by 7 weeks of forcing under LDs and 18 to $22 \mathrm{C}$ before they were marketable (Boyle, 1991a). Therefore, cold treatments would have to begin by early September and end by mid-October, and would occur at a time of the year when average daily temperatures exceed 10C in many areas of North
America. An alternative would be to select clones that would set buds at supraoptimal temperatures $(>10 \mathrm{C})$. The present study was conducted to determine the influence of temperature and clonal genotype on flowering of Easter cactus.

\section{Materials and Methods}

General procedures. Plants were propagated and grown in glasshouses at the Univ. of Massachusetts, Amherst (lat. $42^{\circ} 22.5^{\prime} \mathrm{N}$ ). Unrooted phylloclades of 'Evita', 'Purple Pride', and 'Red Pride' were received from J. de Vries Potplantencultures bv (Aalsmeer, The Netherlands) and were stored at $10 \pm 2.0 \mathrm{C}$ and $90 \%$ relative humidity until propagation (Expt. 1). All other clones were propagated from stock plants maintained at the Univ. of Massachusetts.

A commercial medium composed of sphagnum peat, perlite, and vermiculite (Fafard Growing Mix No. 2; Conrad Fafard, Springfield, Mass.) was used for propagation and growing. The medium was kept evenly moist by irrigating plants every 2 to 5 days. Plants were fertilized weekly with $20 \mathrm{~N}-4.3 \mathrm{P}-16.6 \mathrm{~K}$ $\left(12 \% \mathrm{NO}_{3}-\mathrm{N}, 8 \% \mathrm{NH}_{4}-\mathrm{N}\right)$ at $200 \mathrm{mg} \mathrm{N} /$ liter. Fertilization began after phylloclades were rooted and continued until the experiments ended.

Air temperatures and photosynthetic photon flux (PPF) were monitored with a LI-1000 datalogger (LI-COR, Lincoln, Neb.) equipped with an aspirated LI-1000-16 thermistor and a LI-190SA quantum sensor. The datalogger was configured with a sampling interval of 60 sec and recorded mean PPF and temperature values at 1 -h intervals. Shading compound (Kool Ray; Continental Products Co., Euclid, Ohio) was applied to the glass to maintain the PPFbelow $650 \mu \mathrm{mol} \cdot \mathrm{m}^{-2} \cdot \mathrm{s}^{-1}$. Plants were grown under natural daylengths (ND) and $18 \pm 2.0 \mathrm{C}$ minimum from propagation until the start of experiments, and plants remained vegetative throughout this period.

Clones and night temperatures. 'Crimson Giant', 'Evita', 'Purple Pride', and 'Red Pride' were propagated on 14 Apr. 1989 in 60-cell plastic trays, using two phylloclades per 70$\mathrm{cm}^{3}$ cell. In mid-July, rooted phylloclades were planted, two plants (one cell) per pot, into 520$\mathrm{cm}^{3}$ (10 $\mathrm{cm}$ in diameter) plastic pots. Each plant consisted of three or four tiers of mature phylloclades by late November. On 24 Nov., pots were transferred to either 1) $10 \pm 2.0 \mathrm{C}$ nights $/ 12 \pm 2.0 \mathrm{C}$ days and ND (10/ND), or 2$)$ $18 \pm 2.0 \mathrm{C}$ nights $/ 21 \pm 2.0 \mathrm{C}$ days and ND (18/ ND). Plants remained in $10 / \mathrm{ND}$ or $18 / \mathrm{ND}$ for 6 weeks. ND ranged from 9 to $9.5 \mathrm{~h}$ during the 6-week period (List, 1951). On 5 Jan. 1990, plants were transferred to $18 \pm 2.0 \mathrm{C}$ nights $/ 21$ $\pm 2.0 \mathrm{C}$ days and LDs (18/LD). LDs were achieved by supplementing ND with 25 to 35 $\mu \mathrm{mol} \cdot \mathrm{m}^{-2} \cdot \mathrm{s}^{-1}$ (400 to $700 \mathrm{~nm}$ ) irradiance from 400-W, high-pressure sodium lamps (LU400; Canadian General Electric Co., Toronto, Ont.) from 1600 to $2200 \mathrm{HR}$ (Boyle, 1991b). Plants remained under 18/LD until the experiment ended (15 Apr. 1990). There were 10 pots per clone per initial environment (10/ND or 18/ 
ND). Pots were completely randomized within initial environments and were re-randomized when transferred to the final environment (18/ LD). Pots were spaced on $25-\mathrm{cm}$ centers throughout the experiment.

Data were collected when the first flower reached anthesis in each pot or when the experiment ended. Days to flowering (from the start of 18/LD), number of apical phylloclades, percentage of apical phylloclades flowering, and number of flower buds were recorded. Data were analyzed by SAS's (1985) General Linear Model (GLM) procedure. Initial environments were not replicated, and therefore were analyzed separately. Values for percentage of apical phylloclades flowering were arcsin-transformed $\left(\sin ^{-1} \sqrt{\%}\right)$ before analysis . Analysis of covariance was performed on the number of flower buds per pot, with number of apical phylloclades per plant as the covariate. The percentage of plants flowering was calculated for each clone, and chi-square tests were used to test for differences among clones.

Clonal comparison. Twenty-three clones (genotypes) were evaluated in this study. Stem cuttings, consisting of one to five phylloclades each, were propagated on 3 Mar. 1992 in 72cell plastic trays, using two cuttings per 65$\mathrm{cm}^{3}$ cell. Phylloclade size varied substantially among the 23 clones (data not presented), and therefore the number of phylloclades per cutting was adjusted from one to five to equalize propagule size. For example, clones with small phylloclades were propagated by cuttings consisting of up to five phylloclades each, whereas clones with the largest phylloclades were propagated by cuttings consisting of one phylloclade each. Each plant consisted of two to four tiers of mature phylloclades by late September. On 21 Sept., all plants were transferred to $18 \pm 2.0 \mathrm{C}$ nights $/ 21 \pm 2.5 \mathrm{C}$ days and 8-h SDs (18/SD). SDs were provided by covering plants with black sateen cloth from 1600 to $0800 \mathrm{HR}$. Six weeks later (2 Nov.), plants were transferred to $18 / \mathrm{LD}$ (as described in Expt. 1). Plants remained under 18/LD until the experiment ended (10 Feb. 1993). The experiment was a completely randomized design with 12 cells per clone and two plants per cell. Before the start of $18 / \mathrm{SD}$, cells were completely randomized in 72-cell trays and were placed on $9.0-\mathrm{cm}$ centers.

Data were collected on the same variables described in Expt. 1. Values for percentage of apical phylloclades flowering were arcsintransformed before statistical analysis. Data were analyzed by the GLM procedure (SAS Institute, 1985). A hierarchical classification was used to separate clonal effects, experimental error (variation among cells within clones), and sampling error (variation among plants within cells) (Steel and Torrie, 1980). Covariance analysis was performed on the number of flower buds per plant, using the number of apical phylloclades per plant as the covariate. The percentage of plants flowering was calculated for each clone, and chi-square tests were used to test for differences among clones.

\section{Results}

Clones and night temperatures. All plants of 'Crimson Giant', 'Evita', and 'Red Pride' flowered, but flowers developed on only $50 \%$ of the 'Purple Pride' plants exposed to $18 / \mathrm{ND}$ (Table 1). For both initial environments, there were significant differences between clones for number of apical phylloclades, percentage of apical phylloclades flowering, and number of flower buds. Generally, 'Crimson Giant' exhibited the highest percentage of apical phyl- loclades flowering and the most flower buds. 'Crimson Giant' produced the most flower buds, regardless of initial environment, when the number of buds was adjusted to an equivalent number of apical phylloclades by covariance analysis. Time to flowering was not significantly influenced by clonal genotype, but plants exposed to 18/ND for 6 weeks flowered 11 to 14 days later than those given 10/ND for an equivalent span.

Increasing the NT from 10 to $18 \mathrm{C}$ for 6 weeks inhibited flowering of all clones, but to different degrees. Exposure to 18/ND decreased the percentage of apical phylloclades flowering more for 'Evita', 'Purple Pride', and 'Red Pride' than for 'Crimson Giant' (Table 1). Relative to 10/ND, exposure to 18/ ND resulted in an $84 \%$ to $95 \%$ decrease in the number of flower buds for 'Evita', 'Purple Pride', and 'Red Pride', but only an $\approx 50 \%$ decrease in the number of flower buds for 'Crimson Giant'. These responses indicate the existence of a strong genotype $\times$ environmental interaction for flowering in Easter cactus.

Clonal comparison. The 23 clones differed significantly in percentage of flowering plants, days to flowering, number of apical phylloclades, percentage of apical phylloclades flowering, and number of flower buds (Table 2). All 'Crimson Giant' plants produced flowers, but $\leq 75 \%$ of the plants flowered for the other 22 clones. Furthermore, 'Crimson Giant' exhibited the highest percentage of apical phylloclades flowering and the most flower buds among the 23 clones. The clones also differed in the number of flower buds when adjusted for an equivalent number of apical phylloclades by covariance analysis (Table 2). 'Crimson Giant' yielded the most flower buds, followed by CL U1, R891-11, CL 32, and 'Yvonne Pelham', among the adjusted means.

Table 1. Influence of initial environment $[10 \pm 2.0 \mathrm{C}$ nights/12 $\pm 2.0 \mathrm{C}$ days and natural daylengths (10/ND) or $18 \pm 2.0 \mathrm{C}$ nights/21 $\pm 2.0 \mathrm{C}$ days and natural daylengths $(18 / \mathrm{ND})]$ on flowering of four Easter cactus clones (Expt. 1). Plants were exposed to 10/ND or 18/ND for 6 weeks, then transferred to $18 \pm 2.0 \mathrm{C}$ nights/21 \pm $2.0 \mathrm{C}$ days and long days (18/LD).

\begin{tabular}{|c|c|c|c|c|c|c|c|}
\hline \multirow[b]{3}{*}{ Clone } & \multirow{3}{*}{$\begin{array}{c}\text { Plants } \\
\text { flowering } \\
(\%) \\
\end{array}$} & \multirow{3}{*}{$\begin{array}{c}\text { Days to } \\
\text { flowering } \\
\text { (no.) }\end{array}$} & \multirow{3}{*}{$\begin{array}{c}\text { Apical } \\
\text { phylloclades } \\
\text { (no./pot) }\end{array}$} & \multirow{2}{*}{\multicolumn{2}{|c|}{$\begin{array}{c}\text { Apical } \\
\text { phylloclades } \\
\text { flowering }\end{array}$}} & \multicolumn{2}{|c|}{$\begin{array}{l}\text { Flower buds } \\
\text { (no./pot) }\end{array}$} \\
\hline & & & & & & \multirow{2}{*}{$\begin{array}{l}\text { Actual } \\
\text { means }\end{array}$} & \multirow{2}{*}{$\begin{array}{l}\text { Adjusted } \\
\text { means }^{y}\end{array}$} \\
\hline & & & & $(\%)$ & {$[\mathrm{AT}]$} & & \\
\hline \multicolumn{8}{|c|}{ Initial $10 / N D-$ Final $18 / L D^{x}$} \\
\hline Crimson Giant & 100 & 62 & 25 & 91 & [74] & 67.7 & 78.3 \\
\hline Evita & 100 & 62 & 39 & 72 & [58] & 51.8 & 36.4 \\
\hline Purple Pride & 100 & 62 & 29 & 68 & [56] & 52.3 & 55.2 \\
\hline Red Pride & 100 & 65 & 30 & 90 & {$[73]$} & 59.8 & 61.7 \\
\hline $\mathrm{LSD}_{0.05}$ & & & 4 & & {$[7]$} & 10.9 & 7.5 \\
\hline Significance & & & & & & & \\
\hline Clones & & NS & $* * *$ & & $* * *$ & $*$ & $* * *$ \\
\hline Apical phylloclades & & --- & --- & & --- & --- & $* * *$ \\
\hline \multicolumn{8}{|c|}{ Initial $18 / N D-$ Final $18 / L D^{x}$} \\
\hline Crimson Giant & 100 & 76 & 21 & 72 & [59] & 34.2 & 38.0 \\
\hline Evita & 100 & 73 & 41 & 18 & [24] & 8.2 & 3.1 \\
\hline Purple Pride & $50^{\mathrm{w}}$ & 75 & 30 & 6 & [9] & 2.7 & 2.4 \\
\hline Red Pride & 100 & 78 & 26 & 22 & {$[27]$} & 6.7 & 8.3 \\
\hline $\begin{array}{l}\mathrm{LSD}_{0.05} \\
\text { Significance }\end{array}$ & & & 4 & & {$[8]$} & 5.1 & 4.9 \\
\hline Clones & & NS & $* * *$ & & $* * *$ & $* * *$ & $* * *$ \\
\hline Apical phylloclades & & --- & --- & & --- & --- & NS \\
\hline
\end{tabular}

${ }^{2}$ Percentage (\%) and arcsin-transformed [AT] data.

${ }^{\mathrm{y}}$ Means calculated using number of apical phylloclades per plant as the covariate.

× 10 or $18 \mathrm{C}$ nights, 9 - to 9.5 -h ND, or $\approx 14-\mathrm{h}$ LD.

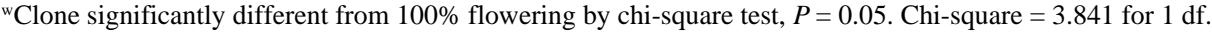

ss, *,*** Nonsignificant or significant at $P \leq 0.05$ or 0.001 , respectively. 
Table 2. Flowering responses of 23 Easter cactus clones grown at $18 \mathrm{C}$ minimum temperature (Expt. 2 ). Plants were exposed to $18 \pm 2.0 \mathrm{C}$ nights $/ 21 \pm 2.5 \mathrm{C}$ days and 8 -h short days for 6 weeks, then transferred to $18 \pm 2.0 \mathrm{C}$ nights $/ 21 \pm 2.0 \mathrm{C}$ days and long days.

\begin{tabular}{|c|c|c|c|c|c|c|c|c|}
\hline \multirow[b]{3}{*}{ Clone } & \multirow[b]{3}{*}{ Source $^{y}$} & \multirow{3}{*}{$\begin{array}{c}\text { Plants } \\
\text { flowering } \\
(\%)^{\mathrm{x}}\end{array}$} & \multirow{3}{*}{ 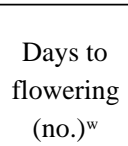 } & \multirow{3}{*}{$\begin{array}{c}\text { Apical } \\
\text { phylloclades } \\
\text { (no./plant) }\end{array}$} & \multirow{2}{*}{\multicolumn{2}{|c|}{$\begin{array}{c}\text { Apical } \\
\text { phylloclades } \\
\text { flowering } \\
\end{array}$}} & \multicolumn{2}{|c|}{$\begin{array}{c}\text { Flower buds } \\
\text { (no./plant) }\end{array}$} \\
\hline & & & & & & & \multirow{2}{*}{$\begin{array}{l}\text { Actual } \\
\text { means }\end{array}$} & \multirow{2}{*}{$\begin{array}{l}\text { Adjusted } \\
\text { means }\end{array}$} \\
\hline & & & & & $\overline{(\%)}$ & $\overline{[\mathrm{ATT}]}$ & & \\
\hline Annika & PM & 0 & --- & 10 & 0 & {$[0]$} & 0 & 0.1 \\
\hline Cassiopeia & PM & 4 & 106 & 9 & $<1$ & {$[1]$} & 0.1 & 0.2 \\
\hline Crimson Giant & MD & 100 & $73 \pm 1$ & 9 & 47 & [44] & 4.3 & 4.4 \\
\hline CL 16 & $\mathrm{CL}$ & 0 & --- & 15 & 0 & [0] & 0 & -0.1 \\
\hline CL 32 & $\mathrm{CL}$ & 29 & $71 \pm 1$ & 11 & 13 & [14] & 1.5 & 1.6 \\
\hline CL U1 & $\mathrm{CL}$ & 75 & $71 \pm 1$ & 15 & 21 & [23] & 3.2 & 3.1 \\
\hline CL U3 & CL & 0 & -- & 16 & 0 & [0] & 0 & -0.1 \\
\hline Evita & JV & 0 & --- & 9 & 0 & {$[0]$} & 0 & 0.1 \\
\hline Flash & RG & 0 & --- & 11 & 0 & {$[0]$} & 0 & 0 \\
\hline Hatherton Star & RG & 0 & --- & 8 & 0 & {$[0]$} & 0 & 0.1 \\
\hline Leo's Pink & RG & 0 & --- & 16 & 0 & {$[0]$} & 0 & -0.1 \\
\hline Monarch & RG & 0 & --- & 11 & 0 & [0] & 0 & 0.1 \\
\hline Pink Perfection & RG & 0 & --- & 14 & 0 & {$[0]$} & 0 & 0 \\
\hline Purple Pride & JV & 4 & 79 & 7 & $<1$ & {$[<1]$} & $<0.1$ & 0.2 \\
\hline Rhipsalidopsis rosea & $\mathrm{MD}$ & 4 & 62 & 23 & $<1$ & {$[<1]$} & $<0.1$ & -0.3 \\
\hline R891-4 & MA & 0 & --- & 14 & 0 & {$[0]$} & 0 & 0 \\
\hline R891-9 & MA & 21 & $64 \pm 2$ & 12 & 5 & [6] & 0.5 & 0.6 \\
\hline R891-11 & MA & 46 & $73 \pm 1$ & 13 & 14 & {$[16]$} & 1.9 & 1.9 \\
\hline R891-13 & MA & 8 & $77 \pm 1$ & 9 & 1 & {$[2]$} & 0.1 & 0.2 \\
\hline Shocking Pink & RG & 8 & $86 \pm 3$ & 11 & 1 & [2] & 0.1 & 0.2 \\
\hline Sutter's Gold & RG & 0 & --- & 15 & 0 & {$[0]$} & 0 & -0.1 \\
\hline Thor-Anne & GT & 17 & $96 \pm 2$ & 5 & 4 & [5] & 0.2 & 0.4 \\
\hline Yvonne Pelham & RG & 50 & $67 \pm 1$ & 25 & 5 & [8] & 1.1 & 0.7 \\
\hline $\mathrm{LSD}_{0.05}$ & & & --- & 2 & --- & [4] & 0.5 & 0.6 \\
\hline \multicolumn{9}{|l|}{ Significance } \\
\hline Clones & & & $* * *$ & $* * *$ & --- & $* * *$ & $* * *$ & $* * *$ \\
\hline Cell (within clone) & & & NS & NS & --- & $* * *$ & $* * *$ & --- \\
\hline Apical phylloclades & & & -- & --- & --- & --- & --- & $*$ \\
\hline
\end{tabular}

${ }^{2}$ Percentage $(\%)$ and arcsin-transformed [AT] data.

${ }^{\mathrm{y}} \mathrm{CL}=$ Crystal Lake Greenhouses, Carver, Mass.; GT = Gartneriet Thoruplund, Odense, Denmark; JV = J. de Vries Potplantencultures bv, Aalsmeer, The Netherlands; MA = Univ. of Massachusetts, Amherst; MD = Univ. of Maryland, College Park; PM = Gartneriet PKM, Odense, Denmark; RG = Rainbow Gardens, Vista, Calif.

${ }^{x}$ All clones, except 'Crimson Giant', significantly different from $100 \%$ flowering by chi-square test, $P=0.05$. Chi-square $=3.841$ for 1 df.

wMean $\pm 1 \mathrm{SE}$. The $\mathrm{LSD}_{0.05}$ could not be estimated due to missing values.

${ }^{v}$ Means calculated using number of apical phylloclades per plant as the covariate.

Ns, *,*** Nonsignificant or significant at $P \leq 0.05$ or 0.001 , respectively.

\section{Discussion}

The results of Expts. 1 and 2 demonstrate that clones of Easter cactus vary significantly in their flowering responses at $18 \mathrm{C}$ minimum. The diversity of flowering responses may be attributed to physiological differences between $R$. gaertneri and $R$. rosea. Both species are native to the southeastern Brazilian states of Minas Gerais, Paranà, and Santa Catarina (Scheinvar, 1985). However, R. gaertneri grows at altitudes from 350 to $850 \mathrm{~m}$, whereas $R$. rosea is found at higher elevations, i.e., from 1000 to $2000 \mathrm{~m}$ (Scheinvar, 1985). The obligate low-temperature requirement for flowering displayed by $R$. rosea may be an adaptation to lower temperatures found at higher altitudes, whereas the ability of $R$. gaertner $i$ ('Crimson Giant') to flower at $18 \mathrm{C}$ minimum may have evolved in response to higher temperatures found at lower altitudes. With the exception of $R$. gaertneri 'Crimson Giant' and $R$. rosea, the clones used in Expts. 1 and 2 conform taxonomically to $R$. $\times$ graeseri, as judged from the morphology of the flowers and phylloclades (Barthlott, 1979; Liberty Hyde Bailey Hortorium, 1976). When grown at $18 \mathrm{C}$, most $R$. $\times$ graeseri clones responded like $R$. rosea and produced few or no flowers (Table 2). However, a few $R$. $\times$ graeseri clones (CL U1, R891-11, CL 32, and 'Yvonne
Pelham') displayed flowering responses that were intermediate between 'Crimson Giant' and $R$. rosea (Table 2). Flowering at high temperatures is a complex physiological trait that probably is controlled by numerous genes. The diverse flowering responses observed among the $R$. × graeseri clones (Table 2 ) may be due to segregation of genes controlling flowering.

A 6-week exposure to $18 \mathrm{C} \mathrm{NT}$ resulted in more flowers in Expt. 1 than Expt. 2 for 'Crimson Giant', 'Evita', and 'Purple Pride' (Tables 1 and 2). In both experiments, plants were grown in NDs and at $\approx 18 \mathrm{C}$ minimum before the start of treatments. However, treatments began on 24 Nov. in Expt. 1 and on 21 Sept. in Expt. 2. At 18C, 'Crimson Giant' responds as a SLDP for flowering (Boyle et al., 1988), and the critical daylength for the SD phase is between 11 and $12 \mathrm{~h}$ (Boyle, 1991b). It is feasible that 'Evita' and 'Purple Pride' also respond as SLDPs at $18 \mathrm{C}$. At lat. $42^{\circ} \mathrm{N}$, the duration of daylight is $\leq 11 \mathrm{~h}$ between 17 Oct. and 25 Feb. (List, 1951). Hence, plants in Expt. 1 received natural SDs for at least 5 weeks before the start of treatments ( $24 \mathrm{Nov}$.), whereas plants in Expt. 1 received natural LDs before treatments started (21 Sept.). The supplementary exposure to natural SDs for plants in Expt. 1 may account for their greater flowering compared to plants in Expt. 2.
In Easter cactus, nearly all flower buds develop on apical phylloclades (Boyle et al., 1988; Peters and Rünger, 1971; Rünger, 1960). Therefore, the number of flower buds per plant is functionally related to the number of apical phylloclades per plant. Clonal differences in the number of apical phylloclades were significant in both experiments (Tables 1 and 2), and these differences can be attributed primarily to genetic variation in branching and, in Expt. 2, to variation in number of phylloclades per cutting. Treatments that enhance branching, i.e., pinching or spraying with the growth regulator benzyladenine (BA) (Boyle, 1992), were not practiced in either experiment. Covariance analysis was used to adjust the numbers of flower buds in each experiment to an equivalent number of apical phylloclades, thus permitting a clone's flowering potential to be assessed independently from clonal differences in propagule size or growth habit. For commercial production, however, it would be desirable to obtain clones that are self-branching and capable of flowering at supraoptimal temperatures.

Considerable genotypic variation exists in Easter cactus for flowering at supraoptimal temperatures. However, it is important to note that none of the clones examined in Expt. 2 exhibited prolific flowering (Table 2), indicating that further selection and breeding will be 


\section{Breeding, Cultivars, Rootstocks, \& Germplasm Resources}

required to obtain genotypes that are suitable for commercial production at $18 \mathrm{C}$ minimum. Introduction of Easter cactus cultivars that are capable of flowering at supraoptimal temperatures would extend the marketing period and allow production of flowering plants in warmer climates.

\section{Literature Cited}

Barthlott, W. 1979. Cacti: Botanical aspects, descriptions, and cultivation. Stanley Thornes, Cheltenham, England.

Boyle, T.H. 1990. Flowering of Rhipsalidopsis rosea in response to temperature and photoperiod. HortScience 25:217-219.

Boyle, T.H. 1991a. Commercial production of Eas- ter cactus. Ohio Florists' Assn. Bul. 743:5-6.

Boyle, T.H. 1991b. Temperature and photoperiodic regulation of flowering in 'Crimson Giant' Easter cactus. J. Amer. Soc. Hort. Sci. 116:618622.

Boyle, T.H. 1992. Modification of plant architecture in 'Crimson Giant' Easter cactus with benzyladenine. J. Amer. Soc. Hort. Sci. 117:584589.

Boyle, T.H., D.J. Jacques, and D.P. Stimart. 1988. Influence of photoperiod and growth regulators on flowering of Rhipsalidopsis gaertneri. J. Amer. Soc. Hort. Sci. 113:75-78.

Liberty Hyde Bailey Hortorium. 1976. Hortus third. A concise dictionary of plants cultivated in the United States and Canada. Macmillan Publishing, New York.

List, R.J. 1951. Smithsonian meteorological tables. 6th ed. Smithsonian Inst., Washington, D.C.

Nell, T. 1988. Easter cactus-A new crop for American growers. GrowerTalks 52(5):84, 86, 88.

Peters, J. and W. Rünger. 1971. Blütenbildung von Rhipsalidopsis gaertneri. Gartenbauwissenschaft 36:155-174.

Rünger, W. 1960. Über den Einfluß der Temperatur und der Tageslänge auf die Blütenbildung von Rhipsalidopsis $\times$ graeseri. Zeitschrift Bot. 48:381-397.

SAS Institute. 1985. SAS/STAT guide for personal computers. version 6 ed. SAS Inst., Cary, N.C.

Scheinvar, L. 1985. Cactáceas. Herbario "Barbosa Rodrigues", Itajaí, Santa Catarina, Brazil.

Steel, R.G.D. and J.H. Torrie. 1980. Principles and procedures of statistics. 2nd ed. McGraw-Hill, New York. 